Abstracta Iranica

Revue bibliographique pour le domaine irano-aryen

Volume 34-35-36 | 2017

Comptes rendus des publications de 2011-2013

\title{
Pierre Amiet. À Pasargades : autels du feu ou soubassements de tours? Une suggestion
}

\section{Astrid Nunn}

\section{(2) OpenEdition}

1 Journals

\section{Édition électronique}

URL : http://journals.openedition.org/abstractairanica/41684

DOI : 10.4000/abstractairanica.41684

ISSN : 1961-960X

Éditeur :

CNRS (UMR 7528 Mondes iraniens et indiens), Éditions de l'IFRI

Référence électronique

Astrid Nunn, "Pierre Amiet. À Pasargades : autels du feu ou soubassements de tours ? Une suggestion », Abstracta Iranica [En ligne], Volume 34-35-36 | 2017, document 84, mis en ligne le 15 juillet 2016, consulté le 30 septembre 2020. URL : http://journals.openedition.org/abstractairanica/41684; DOI : https://doi.org/10.4000/abstractairanica.41684

Ce document a été généré automatiquement le 30 septembre 2020.

Tous droits réservés 


\title{
Pierre Amiet. À Pasargades : autels du feu ou soubassements de tours? Une suggestion
}

\author{
Astrid Nunn
}

\section{RÉFÉRENCE}

Pierre Amiet. « À Pasargades : autels du feu ou soubassements de tours ? Une suggestion ». ARTA, 2013.001, 9 p. http://www.achemenet.com/arta/2013.001Amiet.pdf

1 L'A. s'attache aux deux « cubes » de pierre situés au nord-ouest des palais et du jardin de Pasargades. Ces cubes sont communément interprétés comme des autels, interprétation que l'A. réfute. Il préfère $\mathrm{y}$ voir des soubassements de tours. Effectivement l'escalier du cube sud ressemble à ceux des tours de Zendān-e Soleymān et de Naqš-e Rostam. L'A. complète ainsi la structure par une tour en bois dont les poutres auraient été insérées dans les décrochements de surface.

\section{AUTEURS}

\section{ASTRID NUNN}

Université de Munich 